\title{
DOMINANTS OF DEVELOPMENT AND REPRODUCTION OF HUMAN CAPITAL AS A STRATEGIC COMPONENT OF CHANGE
}

\author{
Nadiia Benko'
}

\begin{abstract}
The subject of the study is the conceptual, theoretical, methodological and applied provisions of state regulation of development and reproduction of human capital for the national economic system management. Methodology. General scientific methods were used in the research process. The method of comparison was used for generalizing the approaches of different researchers on the main dominants of development and reproduction of human capital. Analysis was used to determine the quantitative and qualitative parameters of the dominants of human capital. Synthesis was used to determine the methodological principles of labour market regulation and human capital development. Induction and deduction were used for determining approaches to the main dominants of human capital. The aim of the article is to generalize various approaches to the main dominants of development and reproduction of human capital on different bases and purposes, to develop a modern theoretical basis for the development of human capital in the country's economy. The results of the study have shown that to ensure the effectiveness of state regulation of the development and reproduction of human capital, it is necessary to create an appropriate social environment and conditions that promote the fullest use of knowledge and intellectual, creative potential of individuals. Conclusion. The composition of the bases and goals of the dominants of development and reproduction of human capital in Ukraine, in contrast to the existing one, should include labour market regulation policy, national model of combating unemployment, working capacity, cost of human capital and human development index. This will ensure investment, development and human capital management in Ukraine. Analysis of the methodo-logical principles of labor market regulation and human capital development of the European Union and Ukraine, and problems of human capital development in Ukraine allowed us to conclude that they differ significantly. Their difference is ex-plained by different levels of economic and social situation of countries and other factors, in particular the low speed of dissemination and implementation of progres-sive results of investment in education and science. The practical significance lies in increasing the scientific substantiation of theoretical provisions and practical measures to ensure the mechanism of state regulation of development and reproduc-tion of human capital is in accordance with transformational changes in social rela-tions and market conditions, processes of globalization.
\end{abstract}

Key words: human capital, human potential, dominants of human capital, tools to promote employment, tools to promote human capital.

JEL Classification: B22, E22, E24, J24, 015

\section{Introduction}

The modern historical stage of development of a society is characterized by the formation of the economy of knowledge, innovations, global information systems, the economics of intellectual labour, science, new technologies. Most of the researchers recognize the importance of human capital in the new economy, which is the main, intensive productive factor in the socio-economic development of modern society and an individual. Different countries are at different stages of socio-economic development, have different resource potential, and set different goals based on political and economic interests. Human capital is inextricably present in the field of these tasks as a strategic component of change. A fairly stable component structure of human capital has been formed in the theory of human capital. For the theoretical substantiation of the state programs of development of human capital, it is necessary to allocate dominants of its development and reproduction. In

\footnotetext{
Corresponding author:

${ }^{1}$ National Academy of Management, Ukraine.

E-mail: nadiya.benko@gmail.com

ORCID: https://orcid.org/0000-0002-0542-5839
} 
the scientific works of recent decades, the approaches of individual authors to the main dominants of the development and reproduction of human capital on different bases and goals have been formed, however, there is no unity on this issue.

The contribution to the development of concepts of human capital as a resource of socio-economic development, research of the dominants of development and reproduction of human capital was made by foreign researchers, in particular: McClellan D. C., Spenser L. M., Spenser S. M., Smyrnov V. T., Soshnykov I. V., Romanchyn V. I., Skobliakova I. V., Boyatzis R., Chyzhova E. N., Alwan Kh. A.

The results of research by the following Ukrainian scientists were useful: Tymoshenko K. V., Nosyk O. M., Polous O. V., Dotsenko A. I., Krayevska G. A., Tereshchenko D. A., Melnychuk D. P., Semykina A. V.

Scientists emphasize the importance of specific groups of human abilities as a resource in socioeconomic development. In particular, in an industrial society, the concept of assessment of professional skills and abilities of workers due to the re-quirements of scientific and technological progress was dominant. In the period of the new economy, the concept comes to the fore in which the assessment of professional competencies is supplemented by an assessment of personal characteristics and social-labour relations of employees that affect the effectiveness of their work. This led to scientific controversy about the dominants of development and reproduction of human capital, their importance, and priority.

\section{Research of approaches to the dominants of development and reproduction of human capital}

The main reason for the need to actualize the role of human capital in the de-velopment of modern society is the transformation of the economic system and society as a whole under the influence of scientific, technological, and information revolutions. This leads to the need to form a completely different type of employee. In these conditions, such characteristics of the employee as creativity, ability to innovate, a high degree of adaptation to advanced innovative technologies, the ability to make quick and correct management decisions come to the fore. That is, the employee must not only be a highly qualified professional but also have a developed creative intelligence (Tymoshenko, 2018).

We can identify the following basic human capital elements of an individual:

- knowledge, which is an appropriate form of information used in economic activities, which increases efficiency; - abilities, namely, the ability to successfully perform any activity. There are the following levels of development of abilities: lack of ability (zero level), partial abilities, average abilities, talent, genius;

- experience or skills, skill of performance of concrete labor operations for a long time;

- culture - principles and stereotypes of behavior within the existing knowledge, rules, traditions, morals in society;

- motivation - the direction of activity, its intensity, satisfaction with the pro-cess and results;

- health;

- cultural and moral capital;

- labour capital;

- organizational and entrepreneurial capital;

- intellectual capital (Smyrnov et al., 2005).

The creative abilities of a person, his or her intellect, intelligence, ability to find non-traditional solutions to complex problems play an exceptional role in the innovation process (Nosyk, 2016).

Adhering to this provision, it can be stated that the transition of societies to the knowledge economy brings to the fore the individual - the bearer of intellectual, creative abilities to innovation. This necessitated the creation of an appropriate social environment and conditions that promote the fullest use of knowledge and intellectual, creative potential of the individual. As a result, the concept of human capital management was born, its intellectual component. Currently, a significant number of different systems of indicators and indices have been developed, which are used to analyze the development of the social environment and conditions that promote the fullest use of human capital, including innovation, educational potential, informatization of society, use of information and communication technologies, etc.

As part of the study of human capital over the past decades, the main domi-nants of its development have gradually formed. The dominants of human capital development are based on various bases and purposes, which are presented in the literature on this issue. One of them is "competence" (McClellan, 1973). Competence is increasingly used in the study of the potential of human capital carriers. The concept of competence does not have a single definition. In general, it is a cumulative assessment of some elements of human capital. Competence is a characteristic of an individual that has a causal connection with his or her work. This characteristic includes skills, like communication skills and motives. The greatest attention to the conceptualization of the concept of competence is paid in various studies of the effectiveness of organizations, management, and human resources. Boyatsis, R. (Boyatsis, 2008) has made a great contribution to the development of the concept of competency. In order to study characteristics that are directly related to the effectiveness of managers - employees of organizations, regardless of their specifics, Boyatsis identifies 19 managerial competencies: 
- focus on efficiency (desire to do something better than others);

- proactivity (intention to act on a task);

- diagnostic use of competencies (a way of thinking

that uses certain models and concepts to ensure what is happening);

- trying to make an impact;

- self-confidence;

- use of oral presentations (effectiveness of communication);

- logical thinking (a process of thinking in which certain events are considered in causal connection with other events);

- conceptualization (the ability to create your own concept that describes a particular event);

- use of social influence (use of one's influence to create a team, alliance, network, coalition);

- positive attitude (trust in people);

- group process management;

- accurate self-assessment;

- development of others;

- unilateral use of power (directiveness);

- spontaneity (ability to easily and freely express oneself in appropriate conditions);

- self-control (subordination of own desires to the needs of the organization);

- objectivity of perception;

- internal balance and adaptability (patience at work

and a correct understanding of changes in life and organization);

- focus on relationships (attempts to build relationships with others) (TRN.ua training portal, 2020).

Based on the competency approach, Spenser L. and Spenser S. identified the following components of competencies:

- Reasons;

- Psychophysiological features;

- Human's belief in his or her ability to act effectively;

- Knowledge;

- Habits (Spenser L. and Spenser S., 2005).

This structure of competence adequately fits into the theory of human capital.

Polous, O. (2017) identifies the dominants of human capital development in Ukraine in the context of compliance with the convergence criteria of the European Union (EU) and, in particular, the implementation of the Maastricht criteria (convergence criteria):

- inflation should not exceed more than $1.5 \%$ - the average value of the three member states of the European Union with the most stable prices;

- long-term interest rates on government bonds should not exceed more than $2 \%$ - the average value of the relevant rates in countries with the lowest inflation;

- the exchange rate must not go beyond the established corridor during the last two years $(+/-15 \%)$;

- public debt must be less than $60 \%$ of GDP;

- the state budget deficit should not exceed 3\% of GDP.
According to the criteria's estimates, Ukraine has risen sharply in terms of "creative products", which include the development of high value-added products, IT products, design, media, fashion, and more. This happened also due to the digitalization of the economy, its gradual transformation into an economy with a high level of use of IT technologies. Medium and small businesses are increasingly using the opportunities of the Internet and IT as tools to grow their business.

Thus, the dominants of human capital development in Ukraine should be considered in the context of meeting the convergence criteria. It is necessary to continue the pension reform, administrative reform to optimize the number of civil servants (except for education, which plays a key role in the formation of human capital, and health care, which supports its development). There is also a need to change the tax burden to increase wages and reduce the level of labor migration and to promote investment in Ukrainian business, as well as to stimulate automation, robotization of Ukrainian business and bring it to an innovative level (Polous, 2017).

Another dominant of human capital development is studied by Dotsenko, A. and Krayevska, G., which is the reproduction of human capital of Ukrainian settlements, in particular rural settlements. The researchers concluded that:

- At the present stage in Ukraine, there is a regressive regime of reproduction of human capital, due to the deepening of the negative process of depopulation;

- The main trend in the reproduction of human capital is the change of generations, and the number of new generations is less than the generations that are dying;

- Hence, the main conclusion is the priority of the reproduction of human capital not quantitatively but qualitatively;

- Qualitative changes in the structure and reproduction of human capital are in the increase of the working age share of people and people who are in good health, who have a complete general secondary and higher education (especially in rural settlements where the share of people with higher education is almost three times less than in urban);

- The process of reproduction of human capital has significant differences in urban and rural areas of Ukraine, which led to the emergence of depressed rural are-as;

- Shifts in the sex and age structure of the rural population have led to a ten-dency to reduce the workload of the working population by younger and older people of working age (Dotsenko and Krayevska, 2011).

In the study of modern dominants of human capital development, Tereshchenko D. identifies the requirements dictated by the Fourth Industrial Revolution. The study confirmed the key role of education in the formation of human capital. The results show that the main indicators of Ukraine in the field of education do not allow to reproduce human capital in 
accordance with modern technological challenges, so timely measures by the state require the implementation of policies aimed at overcoming Ukraine's lag in productivity, education and other indicators, which allow to implement the concept of "Industry 4.0" due to the growing quality of human capital. The author proves that the global concept of "Industry 4.0", which demonstrates modern changes in technology, methods of reproduction and the real needs of innovation, demonstrates certain features of approaches to the formation of human capital. The timely implementation of a high-tech path of economic development will allow states to achieve significant growth. Ukraine lags far behind in terms of opportunities to introduce modern production and form an appropriate level of human capital. It is concluded that having significant scientific and educational potential, Ukraine should accelerate the modernization of education, science, innovation through legal, administrative, economic, and other mechanisms of public administration and change approaches to ways of forming human capital (Tereshchenko, 2019).

Melnychuk D. defines education as the starting point for the development of human capital, a major factor in the modernization of society because the personal and professional development of citizens is the most important prerequisite for effective modernization. There is no doubt that education contributes to the modernization of societies, and serves as a basis for the development of knowledge-intensive industries, the introduction of advanced technologies in economic practice. The author argues that the negative trend in Ukrainian education will progress until the volume of enrolment in higher educational institutions and lists of specialties do not meet the real personnel demands that are formed at all levels of the economic system of society. Currently, education is a secondary tool of social management, but it should become a leading institution for the development of professional qualities of citizens who are capable of ensuring high productivity and innovative results. The scientist concludes that the main reason that hinders the development of education and training is that the domestic economy is dominated by jobs of low technological complexity, which are unattractive for modern professionals, especially young people. The productive capacities of the vast majority of the economically active population remain underdeveloped. That is why investments in the formation of human capital must be accompanied by the revival of the productive sphere, supported by investments in the comprehensive development of enterprises. Technical and technological modernization of economic sectors is the most important prerequisite for high efficiency of processes in the field of human capital management (Melnychuk, 2015).

Nosyk O. states that the economic component of innovative development is the starting point of human capital development. From the scientist's point of view, human capital as the value of knowledge, skills, and abilities accumulated by a person, which grows in the process of its use in various spheres of public life, on the one hand, is a basic resource of innovative development. On the other hand, the development of an innovative economy causes certain transformations of human capital, the generalizing manifestation of which is the increase in its level of innovation, as the ability to perceive innovation - the focus on creating, implementing, and using innovations. In the context of reproduction of human capital of innovative type, the researcher determines the unity of human lifetime: birth, investment, elementary development, basic development, the professionalization of knowledge, practical activities, aging; and cycles of investments in its development: formation, accumulation, realization in productive activity and incomes from it (Nosyk, 2016).

In unison with Nosyk O., some foreign scientists like Smyrnov V., Soshnykov I., Romanchyn V. and Skobliakova I., see the innovative sector of the economy and its development as the starting point of human capital development (Smyrnov et al., 2005).

Semykina A. determines competitiveness as the main dominant of human capital development. As trends that play a dominant role in the development of human capital in Ukraine and the formation of its competitiveness, the scientist defines:

1) Development of the national labour market, employment services, freedom of choice;

2) Population decline in Ukraine as a result of a demographic crisis;

3) The phenomenon of "aging" of the population;

4) Trends of deteriorating health of the population;

5) Reduction in the number of employees due to the demographic crisis and structural changes in employment;

6) Reducing the inflow of young labour to enterprises;

7) Trends in stagnation in economic activity, rising unemployment;

8) Stably high share of employees in conditions that do not meet sanitary and hygienic standards: exposure to harmful factors, exceeding the maximum allowable noise, ultrasound, infrasound, exposure to chemicals, dust, vibration, etc., hard physical labour;

9) Low level of mechanization, automation, intellectualization of labour;

10) Increasing labour mobility in employment, training;

11) Quality of knowledge in the field of school education, vocational and higher education;

12) Increasing the share of full-time employees with higher education;

13) Salaries;

17) Increasing the competitiveness of human capital (Semykina, 2018). 
As the scientist emphasizes, only three of them have positive effects on in-creasing the competitiveness of human capital, which are: the development of the national labour market, employment services, freedom of labour choice; increase in the share of full-time employees with higher education; growth of labour mobility in labour activities, training.

The dominants of human capital development, from the standpoint of Chyzhova E., determine the features and characteristics of the knowledge economy, its essential differences from the standard market economy. After all, it has other pat-terns and mechanisms. This is, in particular, the transition from an industrial econo-my to a science-intensive new economy with intensive use of science-based on intellectual sources (Chyzhova, 2015).

According to the World Economic Forum, currently, all countries are at different stages of economic development: the first, factorial stage, is typical for countries with the lowest level of development, for which the basis of macroeconomic growth is the mobilization of basic factors of production (land, commodities and unskilled labour); the second, investment stage, covers countries that are integrated into the world economy and use world technologies in domestic production; the third, innovative stage, is related to countries that have made the transition from an economy that imports technology to an economy that creates technology. Here, it is worth noting that the structure of Ukraine's economy does not belong to any of these stages, as it has innovation sectors, investment, and sectors that depend mainly on production factors.

In our opinion, the important dominants of the development and reproduction of human capital in Ukraine and the regulation of investment in human capital are the policy of labour market regulation and national models of combating unemployment, as well as the working capacity of the population. This is confirmed by foreign studies.

According to the European Information and Research Center, most countries implement employment policy and regulate the labour market within the general economic and social policy, as employment is one of the main indicators and ratios of supply and demand in the country. The experience of developed countries shows that in order to solve the problem of unemployment it is necessary not only to regulate the labour market but also to implement economic reforms in all areas of production of products and services (European Information and Research Center, 2020).

The above emphasizes the fundamental thesis that the tools of state regulation of the labour market, mechanisms for regulating the labour market, models for regu-lating the level of employment ensure the proper development and management of human capital.

\section{Approaches to promoting employment and human capital development in the European Union and Ukraine}

According to the results of the study, the following approaches were formed in order to solve the problem in the European Union and Ukraine, which are highlighted in Table 1.

The results of the observations of the Specialized Agency of the European Union were important for the study. The Agency provides advice and support to experts for the EU institutions and partner countries with specific programmes and projects in the field of education and training, lifelong learning, labour market, and employment, social programmes, etc., including Ukraine, in the context of the analysis of the working capacity of the population and policies to improve the development of human capital. As a result, materials were obtained, the analysis of which allowed us to conclude that human capital is the knowledge, competencies, and skills of individuals who are able to mobilize and use them to improve their lives through profitable employment and promote social and economic development; working capacity is the ability of an individual to get an initial job, keep a job and then get a new job. Education and training is an important tool for the development of knowledge, competencies and skills that lead to employment (Human capital and employability in the Mediterranean Region, 2009).

The above emphasizes the need to consider the full development of human capital in Ukraine, which is the main result of the effective work of the Government. If we consider the current situation, it is obvious that the state ineffectively copes with its main task - to provide citizens with all the necessary conditions for the formation, effective use and disclosure of human potential and its high productivity. We believe that the main reason for these unfavourable trends is an insignificant investment in human capital. To immediately address the stated problems, we consider it appropriate to analyse the indicators that confirm the relevance and necessity of investment in human capital.

Today, the condition (value) of human capital in Ukraine is quite sad: the population is rapidly declining and aging; the birth rate is much lower than the level required for simple population reproduction; the share of the working population is declining; labour migration increases, which leads to a loss of intellectual capital. Ukraine had the opportunity to become a prosperous middle-income country, but it is becoming one of the poorest countries in Europe. This disappointing conclusion appeared in the pages of the leading think tank Atlantic Council (Atlantic Council, 2020).

The cost of living is determined based on damages and compensation if a per-son dies or is injured. In European countries, life costs an average from 1 to 2 million EUR. Based on European experience and in order to reduce 
Vol. 7 No. 2, 2021

Table 1

Methodological principles of labour market regulation and human capital development

\begin{tabular}{|c|c|c|c|}
\hline Region & $\begin{array}{l}\text { Approaches / priority tools } \\
\text { to promote employment }\end{array}$ & Goals & $\begin{array}{c}\text { Approaches / priority tools } \\
\text { to promote human capital } \\
\text { development }\end{array}$ \\
\hline 1 & 2 & 3 & 4 \\
\hline European Union & $\begin{array}{l}\text { 1) Youth employment } \\
\text { policies; } \\
\text { 2) High labour mobility; } \\
\text { 3) Encouraging entre- } \\
\text { preneurship. }\end{array}$ & $\begin{array}{l}\text { 1. Providing everyone with a job; } \\
\text { 2. Encouraging entrepreneurship and creating new jobs } \\
\text { through the provision of state guarantees and partial } \\
\text { compensation of wages; } \\
\text { 3. Reforming national employment services and improving } \\
\text { their efficiency; } \\
\text { 4. Openness of labour markets and modernization of the } \\
\text { social protection system; } \\
\text { 5. High mobility of labor in accordance with the demand } \\
\text { and supply for it; } \\
\text { 6. Facilitating the opening of own business through special } \\
\text { training, providing start-up capital and simplified taxation; } \\
\text { 7. Helping young people gain knowledge, skills and } \\
\text { experience to get a real job; } \\
\text { 8. Development of education and training through the EU } \\
\text { grants for study or travel to another country. }\end{array}$ & $\begin{array}{l}\text { 1) Education and training; } \\
\text { 2) Promising and } \\
\text { comprehensive European } \\
\text { migration policy; } \\
\text { 3) Research and innovation; } \\
\text { 4) Social issues. }\end{array}$ \\
\hline Ukraine & $\begin{array}{l}\text { 1) Promotion of } \\
\text { productive employment; } \\
\text { 2) Carrying out an active } \\
\text { employment policy to } \\
\text { accelerate the return of the } \\
\text { unemployed to work; } \\
\text { 3) Creating conditions } \\
\text { for reducing the level of } \\
\text { unofficial employment; } \\
\text { 4) Labour market reform; } \\
\text { 5) Increasing the level } \\
\text { of income of working } \\
\text { citizens; } \\
\text { 6) Deregulation of the } \\
\text { relationship between } \\
\text { employer and employee. }\end{array}$ & $\begin{array}{l}\text { 1. Improving the quality of life and ensuring the } \\
\text { appropriate level of social standards; } \\
\text { 2. Realization of the potential by citizens; } \\
\text { 3. Formation and implementation of effective policies in } \\
\text { the field of education, science, health, social protection and } \\
\text { culture; } \\
\text { 4. Reorientation of the health care system from the policy } \\
\text { of treatment to the policy of strengthening and maintaining } \\
\text { health and disease prevention; } \\
\text { 5. Improving the quality of secondary education, } \\
\text { overcoming territorial differences in the qual-ity of } \\
\text { education and transforming the content of education using } \\
\text { a competency-based approach; } \\
\text { 6. Modernization of vocational education for training at a } \\
\text { high level of competitive workers; } \\
\text { 7. Raising the level and optimizing the results of scientific } \\
\text { and academic activities; } \\
\text { 8. Entry into the top } 50 \text { countries in the human } \\
\text { development index; } \\
\text { 9. Mortality reduction by } 10 \text { percent; } \\
\text { 10. Poverty Reduction (OECD) - } 15 \text { percent. }\end{array}$ & $\begin{array}{l}\text { 1) Formation and } \\
\text { implementation of effective } \\
\text { policies in the field of } \\
\text { education, science, health } \\
\text { care, pensions; } \\
\text { 2) Development of per- } \\
\text { sonality, culture and sports; } \\
\text { spreading the use of the } \\
\text { Ukrainian language in all } \\
\text { spheres of life. }\end{array}$ \\
\hline
\end{tabular}

Source: compiled by the author according to the data (European Information and Research Center, 2020; Official portal of the Verkhovna Rada of Ukraine, 2017; Government portal, 2020).

the number of road accidents, Ukrainian activists organized a study in which experts calculated how much a Ukrainian's life costs. A global study to assess the cost of living and total damage from road accidents was conducted by the Traffic Challenge commissioned by the National Programme for the Prevention of Road Traffic Injuries of Children and Youth (Traffic Challenge, 2020). Today, these data is certified by the auditing company $\mathrm{BDO}$, which is one of the five largest auditors in the world and operates in more than 150 countries. Thus, the cost of living of a Ukrainian, according to some estimates, is from 177,000 to 400,000 USD, and the total annual loss of the state is from 1 billion to 2 billion USD. With an understanding of our own value, we can effectively use people as a resource to achieve a high level of development of the country (Community World Blog, 2020; Ukrainian Truth, 2020; Tsentr Razumkova, 2018).

The value of human capital is directly related to human development. Human development is the expansion of choice so that people can live long and healthy lives, be educated and have the means to live a dignified life. The main dimension of human development is the Human Development Index, which reflects life expectancy, literacy and access to resources. The Human Development Index (HDI) is a combined, synthetic measure of average achievement in three key dimensions of human development: health 
and longevity, knowledge, and a decent standard of living. Today the HDI is used by the United Nations and the World Bank (IBRD) to compare the level of development of countries on the basis of which it is possible to get an idea of the state of human capital in the world. All this is closely linked to the social environment created by improving human capital and labour efficiency (Alwan, 2009).

According to the 2019 Human Development Report published for the United Nations Development Program (UNDP), Ukraine ranks 88th in this indicator, entering the group of countries with a high level of human development. Ahead there is the group of countries (62) with a very high level of human development and 25 countries of the same level, demonstrating the intensity of deprivation of $34.5 \%$ (UN Development Programme, Human Development Report, 2019).

The analysis of the methodological principles of labour market regulation and human capital development of the European Union and Ukraine, reflected in Table 1, and the problems of human capital development in Ukraine, allowed us to conclude that they differ significantly. Their difference is explained by different economic and social situations of countries and other factors, the low speed of dissemination and implementation of progressive results of investment in education and science, in particular. The prospect of solving this problem is opened by the fact that the most obvious way to measure the effect of investment in education for society is to calculate the dependence of GDP growth on increasing the level of education of employees.

Investing in the healthcare system is also a priority dominant of human capital development. This direction first of all provides an increase in the working life of the person that is called to increase the general amount of expenses of time for work, to accelerate a time turn of the aggregated human capital. The health care system monitors the state of health, develops measures to preserve and improve health, which contributes to the restoration and strengthening of biological human capital (Alwan, 2009).

The dominants of human capital development in Ukraine and the main tasks they solve are illustrated in Table 2.

Table 2

Dominants and tasks of development and reproduction of human capital

\begin{tabular}{|c|c|}
\hline \multicolumn{2}{|c|}{ Dominants of development and reproduction of human capital } \\
\hline Basics and goals & Tasks \\
\hline 1 & 2 \\
\hline $\begin{array}{l}\text { Competence (McClellan, 1973; Boyatzis, 2008; TRN.ua training } \\
\text { portal, 2020; Spenser, 2005) }\end{array}$ & Efficiency of management and human resources \\
\hline Compliance with EU convergence criteria (Polous, 2017) & Innovative level of business; creative products \\
\hline $\begin{array}{l}\text { Reproduction of human capital of settlements of Ukraine (Dotsenko } \\
\text { and Krayevska, 2011) }\end{array}$ & $\begin{array}{l}\text { Elimination of depressed rural areas; increasing the share of people } \\
\text { of working age and people who are in satisfactory health, higher } \\
\text { education }\end{array}$ \\
\hline $\begin{array}{l}\text { Requirements of the Fourth Industrial Revolu-tion ("Industry 4.0" } \\
\text { concept) (Tereshchenko, 2019) }\end{array}$ & $\begin{array}{l}\text { Overcoming Ukraine's lag in terms of labour productivity, education } \\
\text { efficiency and other indicators that allow to implement the concept } \\
\text { of "Industry } 4.0 \text { " }\end{array}$ \\
\hline Education (Melnychuk, 2015) & $\begin{array}{l}\text { Personal and professional development of citizens; modernization } \\
\text { of society }\end{array}$ \\
\hline $\begin{array}{l}\text { Economic component of innovation develop-ment (innovation } \\
\text { economy, innovation sector of the economy) (Nosyk, 2016; } \\
\text { Smyrnov et al., 2005) }\end{array}$ & Transformation of human capital, increasing its innovation \\
\hline Competitiveness human capital (Semykina, 2018) & Improving the competitiveness of human capital \\
\hline Knowledge economy (Chyzhova, 2015) & $\begin{array}{l}\text { The transition from an industrial economy to a science-intensive new } \\
\text { economy with intensive use of science based on intellectual sources }\end{array}$ \\
\hline $\begin{array}{l}\text { Labour market regulation and anti-unemployment policy (European } \\
\text { Information and Research Center, 2020; Official portal of the } \\
\text { Verkhovna Rada of Ukraine, 2017; Government portal, 2020; Human } \\
\text { capital and employability in the Mediterranean Region, 2009) }\end{array}$ & $\begin{array}{l}\text { Solving the problems of rising unemployment, outflow and disparity } \\
\text { of labor, reducing the level of real incomes }\end{array}$ \\
\hline $\begin{array}{l}\text { Working capacity of the population (Government portal, 2020; } \\
\text { Human capital and employability in the Mediterranean Region, 2009) }\end{array}$ & $\begin{array}{l}\text { Projects in the field of education and training, health care, lifelong } \\
\text { learning, labor market and employment, social programmes }\end{array}$ \\
\hline $\begin{array}{l}\text { The cost of human capital (Atlantic Council, 2020; Traffic Challenge, } \\
\text { 2020; Community World Blog, 2020; Ukrainian Truth, 2020; Tsentr } \\
\text { Razumkova, 2018; Alwan, 2009) }\end{array}$ & Actualization of investment in human capital \\
\hline $\begin{array}{l}\text { Human Development Index (HDI) (UN Development Programme, } \\
\text { Human Development Re-port, 2019) }\end{array}$ & $\begin{array}{l}\text { Improving the state of human capital and the level of quality of its } \\
\text { content }\end{array}$ \\
\hline
\end{tabular}

Source: compiled by the author 


\section{Survey methodology}

The theoretical and methodological basis of the study are the fundamental provisions of modern economic theory, scientific works of domestic and foreign scientists, research results of international and domestic non-governmental research organizations, the action plan of the Government of Ukraine.

Systemic, process, historical and logical approaches were used to achieve the goal and defined tasks. General scientific methods were used in the research process. The method of comparison was used for generalizing the approaches of different researchers on the main dominants of development and reproduction of human capital. Analysis was used to determine the quantitative and qualitative parameters of the dominants of human capital. Synthesis was used to determine the methodological principles of labour market regulation and human capital development. Induction and deduction were used for determining approaches to the main dominants of human capital.

\section{Conclusion}

The above emphasizes the need to raise the issue of a full development of human capital in Ukraine, which is the main result of the effective work of the government. Overcoming the social crisis will result in a significant improvement in the quality of life and an appropriate level of social standards. The state should help create opportunities for citizens to realize their potential, which affects the growth of the national economy and strengthens Ukraine's competitive position in the world. In view of the above, the government's actions should be aimed at formulating and implementing effective policies in the fields of education, science, health, social protection, and culture, which are of great importance for national identity and pride.

If we consider the current situation, it is obvious that the state ineffectively copes with its main task, which is to provide citizens with all the necessary conditions for the formation, effective use, and disclosure of human potential and its high productivity. We believe that the main reason for these unfavourable trends is an insignificant investment in human capital. Thus, the main problem of modern public policy in the field of education is to find the optimal level of investment in education, which could simultaneously provide access to education for the general population but would not undermine the motivation for private investment in education.

Problems of human capital development in Ukraine and the methodological principles of their solution are also related to the state of the healthcare system and investment in it, which is one of the most important indicators of the state and development of human capital, it is a biological part. Accumulated biological human capital is the physical abilities involved in social reproduction to perform labour operations in their quantitative, qualitative, and value certainty in order to obtain income or other benefits.

\section{References:}

Tymoshenko, K. V. (2018). Investuvannia rozvytku liudskoho kapitalu promyslovoho pidpryiemstva [Investing the development of human capitals of an industrial enterprise] (PhD Thesis), Kharkiv: National Economic University.

Smyrnov, V. T., Soshnykov, I. V., Romanchyn, V. I., \& Skobliakova, I. V. (2005). Chelovecheskii kapital: soderzhanie $i$ vydy, otcenka i stimulirovanie [Human capital: content and types, assessment and incentives]. Orel: Mashinostroenie-1. (in Russian)

Nosyk, O. M. (2016). Liudskyi kapital innovatsiinoho rozvytku: ekonomichni osnovy vidtvorennia [Human capital of innovative development: economic bases of reproduction]. Kharkiv: NFU. (in Ukrainian)

McClelland, D. C. (1973). Testing for competence rather than for intelligence. American Psychologist, no. 28, pp. 1-14.

Boyatzis, R. (2008). Kompetentnyi menedzher. Model effektivnoi raboty [Competent manager. Effective work model]. Moscow: GYPPO. (in Russian)

TRN.ua training portal (2020). Competent manager (according to Boyatsis). Available at: www.trn.ua (accessed November 8, 2020).

Spenser, L. M., Spenser, S. M. (2005). Kompetentcii na rabote. Modeli maksimalnoi effektivnosti raboty [Competencies at work. Models for maximum performance]. Moscow: HIPPO. (in Russian)

Polous, O. V. (2017). Tendentsii rozvytku liudskoho kapitalu Ukrainy v konteksti vidpovidnosti kryteriiam konverhentsii YeS [Trends in the development of human capital in Ukraine in the context of meeting the convergence criteria]. Economy and society. Mukachevo State University, no. 9, pp. 915-922.

Dotsenko, A. I., \& Krayevska, G. A. (2011). Trends in the reproduction of human capital in the settlements of Ukraine. Economic Bulletin of Donbass, no. 2(24), pp. 43-48.

Tereshchenko, D. A. (2019). Modern trends and tendencies in the formation of human capital. Law and public administration, no. 4, pp. 208-214.

Melnychuk, D. P. (2015). Liudskyi kapital: priorytety modernizatsii suspilstva u konteksti polipshennia yakosti zhyttia naselennia [Human capital: priorities for modernization of society in the context of improving the quality of life]. Zhytomyr: Polissia. (in Ukrainian) 
Semykina, A. V. (2018). Liudskyi kapital: pidvyshchennia konkurentospromozhnosti na osnovi sotsiajnykh innovatsii [Human capital: increasing competitiveness through social innovation]. Odesa: «Atlant» VOY SOYU. (in Ukrainian)

Chyzhova, E. N. (2015). Chelovek v innovatcionnoi ekonomike [Man in an innovative economy]. Belgorod: BGTU. (in Russian)

European Information and Research Center (2020). Labour market regulation policy and national models of combating unemployment (world experience). Available at: http://euinfocenter.rada.gov.ua/uploads/ documents/28866.pdf (accessed July 27, 2020).

Official portal of the Verkhovna Rada of Ukraine (2017). On approval of the medium-term plan of priority actions of the Government until 2020 and the plan of priority actions of the Government for 2017. Available at: https://zakon.rada.gov.ua/laws/show/275-2017-\%D1\%80\#Text (accessed July 27, 2020).

Government portal (2020). Human capital development. Available at: https://www.kmu.gov.ua/diyalnist/ reformi/rozvitok-lyudskogo-kapitalu (accessed July 27, 2020).

"Human capital and employability in the Mediterranean Region" 7th Working Session: Towards an economic and employment strategy founded on a knowledge society in the Euromed region Ummuhan Bardak, European Training Foundation Euro-Med Summit of Economic and Social Councils and Similar Institutions Alexandria, 18-19 October 2009. Available at: https://www.eesc.europa.eu/sites/default/files/resources/docs/07bardakdirecteur-etf-en.pdf (accessed July 27, 2020).

Atlantic Council (2020). Available at: https://www.atlanticcouncil.org/issues/ (accessed July 27, 2020).

Traffic Challenge (2020). Available at: http://trafficchallenge.com.ua/ (accessed July 27, 2020).

Community World Blog (2020). The price of human capital. Available at: http://gameblog.woc.org.ua/tsinalyudskogo-kapitalu/ (accessed July 27, 2020).

Ukrainian Truth (2020). How much is the life of a Ukrainian in an accident. Available at: https://life.pravda.com.ua/ health/2017/01/30/222337/ (accessed July 27, 2020).

Tsentr Razumkova (2018). Rozvytok liudskoho kapitalu: na shliakhu do yakisnykh reform [Human capital development: on the way to quality reforms]. Kyiv: Zapovit. (in Ukrainian)

Alwan, Kh. A. (2009). Parameters of a condition and development of the human capital. RUDN Bulletin, Economy series, no. 1, pp. 100-112.

UN Development Programme, Human Development Report (2019). Human Development Report 2019. Available at: http://hdr.undp.org/sites/default/files/hdr_2019_overview_-_russian.pdf (accessed July 27, 2020). 